\title{
Molybdenum(VI) Dichloride Dioxide/Copper(II) Perchlorate: An Efficient Bimetallic Catalyst for Aerobic Oxidation of Alcohols
}

\author{
Kandasamy Jeyakumar and Dillip Kumar Chand* \\ Department of Chemistry, Indian Institute of Technology Madras, Chennai 600036, India
}

\begin{abstract}
The bimetallic system, $\mathrm{MoO}_{2} \mathrm{Cl}_{2} / \mathrm{Cu}\left(\mathrm{ClO}_{4}\right)_{2} \cdot 6 \mathrm{H}_{2} \mathrm{O}$ was used as an efficient catalyst for aerobic oxidation of alcohols. Aromatic, aliphatic, and allylic alcohols; also hydroxy esters were oxidized to the corresponding carbonyl compounds. The bimetallic catalyst showed higher reactivity for alcohol oxidation as compared to individual metal catalysts.
\end{abstract}

Keywords: Molybdenum(VI), copper(II), bimetallic catalyst, alcohol oxidation.

\section{INTRODUCTION}

From synthetic view point, oxidation of alcohols to the corresponding carbonyl compounds is one of the most important reactions in organic synthesis [1]. Chromium, manganese and hypervalent iodine reagents are widely used for alcohol oxidation. However, requirement of stoichiometric amount, safety hazards, formation of by-products and difficulty in work-up are major experimental problems [2]. Recently, catalytic oxidation employing complexes of transition metal ions, such as $\mathrm{Fe}, \mathrm{V}, \mathrm{Cu}, \mathrm{Co}, \mathrm{Pd}, \mathrm{Pt}, \mathrm{Ru}$, etc. in the presence of (2,2,6,6-Tetramethylpiperidine-1-oxyl, i.e. TEMPO)/base are developed [3]. There are only few reports on alcohol oxidation using molybdenum compounds, however, in presence of $\mathrm{H}_{2} \mathrm{O}_{2}$ [4].

The application of bimetallic systems in organic synthesis has emerged in oxidation, coupling and conjugate addition reactions $[5,6]$. There are few reports available on selective oxidation of alcohols to aldehydes or ketones by using bimetallic systems [6]. The use of bimetallic systems for alcohol oxidation can offer the advantage of one metal activating the alcohol while the other activates molecular oxygen and thus results in more efficient catalysis than individual metals.

Recently, molybdenum(VI) dichloride dioxide $\left(\mathrm{MoO}_{2} \mathrm{Cl}_{2}\right)$ has been used as an efficient catalyst for several organic transformations [7]. In our ongoing research work on the catalytic role of $\mathrm{MoO}_{2} \mathrm{Cl}_{2}$, we have reported controlled and selective oxidation of sulfides to sulfoxides/sulfones [8a], aerobic oxidation of secondary and activated primary benzyl alcohols [8b], ring opening reaction of epoxides [8c], C-H insertion of ethyl diazoacetate into aldehydes [8d] and oxidation followed by bromination of $\beta$-hydroxycarbonyls [8e]. Apart from these work, we have also reported copper(II) perchlorate $\left(\mathrm{Cu}\left(\mathrm{ClO}_{4}\right)_{2} \cdot 6 \mathrm{H}_{2} \mathrm{O}\right)$ as an efficient catalyst for acetylation reactions [8f].

Since, $\mathrm{MoO}_{2} \mathrm{Cl}_{2}$ can oxidize only secondary and activated primary benzyl alcohols [8b] modification of the condition is

*Address correspondence to this author at the Department of Chemistry, Indian Institute of Technology Madras, Chennai-600036, India;

Tel: +91(44)22574224; Fax: +91(44)22574202;

E-mail: dillip@iitm.ac.in; d.chand@lycos.com required to widen the scope of alcohol oxidation reaction. Herein we disclose further developments on alcohol oxidation (i.e. oxidation of activated/un-activated benzyl alcohols and aliphatic secondary alcohols) using $\mathrm{MoO}_{2} \mathrm{Cl}_{2} / \mathrm{Cu}\left(\mathrm{ClO}_{4}\right)_{2}$. $6 \mathrm{H}_{2} \mathrm{O}$ as an efficient bimetallic catalyst. The choice of $\mathrm{Cu}(\mathrm{II})$ as a co-catalyst is considered because this metal ion is known to activate molecular oxygen.

\section{EXPERIMENTAL SECTION}

\subsection{General Consideration}

Alcohols 1, 3-16, molybdenum(VI) dichloride dioxide $\left(\mathrm{MoO}_{2} \mathrm{Cl}_{2}\right)$ and copper salts were purchased from Aldrich. Alcohols 2 and 17-21 were prepared by literature methods [9]. Alcohols and solvents were purified before use for the reactions [10]. The products were characterized by recording ${ }^{1} \mathrm{H} \&{ }^{13} \mathrm{C}$ NMR spectra, IR spectra and melting points using Bruker 400 MHz NMR spectrometer, Jasco FT/IR 660 plus and Toshnival-India melting point apparatus respectively. The spectral data are comparable with literature [11].

\subsection{Experimental Procedure for Alcohol Oxidation}

A mixture of $1 \mathrm{mmol}$ of alcohol, $5 \mathrm{~mol} \%$ of $\mathrm{MoO}_{2} \mathrm{Cl}_{2}, 5$ $\mathrm{mol} \%$ of $\mathrm{Cu}\left(\mathrm{ClO}_{4}\right)_{2} \cdot 6 \mathrm{H}_{2} \mathrm{O}$ and $50 \mathrm{mg}$ of $4 \AA$ molecular sieve (MS) in $3 \mathrm{~mL}$ of toluene was stirred under reflux condition while bubbling oxygen. The conversion of alcohol was monitored by thin layer chromatography (TLC). After completion of the reaction, the solvent was evaporated and crude sample was subjected to aqueous work up followed by column chromatography purification to afford the carbonyl compound.

\section{RESULTS AND DISCUSSION}

\subsection{Comparison of Bimetallic Catalyst}

As preliminary study we have tested the oxidation of benzyl alcohol (1) under various conditions (Table 1). The reactions were carried out under reflux in toluene with $10 \mathrm{~mol} \%$ of the catalyst. Molybdenum and copper catalysts alone could not oxidize benzyl alcohol (1) (no product was detected in thin layer chromatography (TLC)) whereas the bimetallic systems i.e. $\mathrm{MoO}_{2} \mathrm{Cl}_{2} / \mathrm{CuX}_{2}$ (where $\mathrm{X}=\mathrm{Cl}, \mathrm{OAc}, \mathrm{NO}_{3}$ and $\mathrm{ClO}_{4}$ ) could oxidize benzyl alcohol (1) to benzaldehyde (1a) in 52-89\% of 
Table 1. Oxidation of Benzyl Alcohol Under Various Conditions $^{\mathrm{a}}$<smiles>OCc1ccccc1</smiles>

1

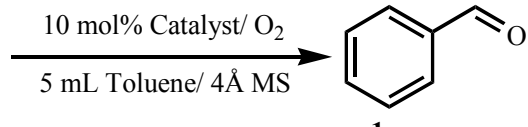

1a

\begin{tabular}{|c|c|c|c|}
\hline Entry & Catalyst & Time (min) & Yield (\%) $^{\mathbf{b}}$ \\
\hline \hline 1 & $10 \mathrm{~mol} \% \mathrm{MoO}_{2} \mathrm{Cl}_{2}$ & 720 & $-^{\mathrm{c}}$ \\
\hline 2 & $10 \mathrm{~mol}^{\mathrm{c}} \mathrm{CuX}_{2}$ & 720 & $-^{\mathrm{c}, \mathrm{d}}$ \\
\hline 3 & $\begin{array}{c}5 \mathrm{~mol} \% \mathrm{MoO}_{2} \mathrm{Cl}_{2} / \\
5 \mathrm{~mol} \% \mathrm{CuX}_{2}\end{array}$ & 720 & $52-89^{\mathrm{d}}$ \\
\hline 4 & $\begin{array}{c}5 \mathrm{~mol} \% \mathrm{MoO}_{2} \mathrm{Cl}_{2} / \\
5 \mathrm{~mol} \% \mathrm{Cu}\left(\mathrm{ClO}_{4}\right)_{2} \cdot 6 \mathrm{H}_{2} \mathrm{O}\end{array}$ & 60 & 89 \\
\hline
\end{tabular}

${ }^{\mathrm{a}}$ Reaction conditions: A mixture of $1 \mathrm{mmol}$ of alcohol, $10 \mathrm{~mol} \%$ of catalyst and $50 \mathrm{mg}$ of $4 \AA$. moleculer sieve was stirred under reflux condition while bubbling oxygen. ${ }^{b}$ Isolated yield. ${ }^{\mathrm{c}}$ No product was detected in thin layer chromatography (TLC). ${ }^{\mathrm{d}} \mathrm{X}=\mathrm{Cl}$, $\mathrm{OAc}, \mathrm{NO}_{3}$ and $\mathrm{ClO}_{4}$

yields. Among the various copper salts used here $\mathrm{Cu}\left(\mathrm{ClO}_{4}\right)_{2}$. $6 \mathrm{H}_{2} \mathrm{O}$ was found to be most efficient when combined with
$\mathrm{MoO}_{2} \mathrm{Cl}_{2}$ to provide $89 \%$ of benzldehyde (1a). Further application of the $\mathrm{MoO}_{2} \mathrm{Cl}_{2} / \mathrm{Cu}\left(\mathrm{ClO}_{4}\right)_{2} \cdot 6 \mathrm{H}_{2} \mathrm{O}$ system was studied by oxidizing various primary benzyl alcohols, aliphatic and aromatic secondary alcohols and hydroxy esters (Tables 2-4).

\subsection{Oxidation of alcohols to aldehydes}

The summarized results for the oxidation of primary benzyl alcohols are provided in Table 2 . The activated primary benzyl alcohols $\mathbf{2}$ and $\mathbf{3}$ (Table $\mathbf{2}$, entries 2 and 3 ) were oxidized to corresponding aldehydes $\mathbf{2 a}$ and $\mathbf{3 a}$ in quantitative yields within 15-30 minutes. It is also interesting to note that these two substrates posses other oxidisable functional groups i.e. tert-amine and sulfide which were intact in the present condition. Deactivated primary benzyl alcohols 4 and 5 (i.e. 4-nitro and 4-bromo benzyl alcohols) and the heterocyclic alcohol i.e. 2-prydine methanol (6) were oxidized to corresponding aldehydes $\mathbf{4 a - 6 a}$ in $62-89 \%$ of yields within 60 minutes. Cinnamyl alcohol (7) was oxidized to cinnamaldehyde (7a) in a good yield without affecting the double bond. The deactivated benzyl alcohol, e.g. 5 is less reactive and provide lower yield of aldehyde as compared to the substrate having electron releasing group on the ring.

Table 2. Oxidation of Primary Benzyl Alcohols Using $\mathrm{MoO}_{2} \mathrm{Cl}_{2} / \mathrm{Cu}\left(\mathrm{ClO}_{4}\right)_{2} \cdot 6 \mathrm{H}_{2} \mathrm{O}$ as the Bimetallic System ${ }^{\mathrm{a}}$

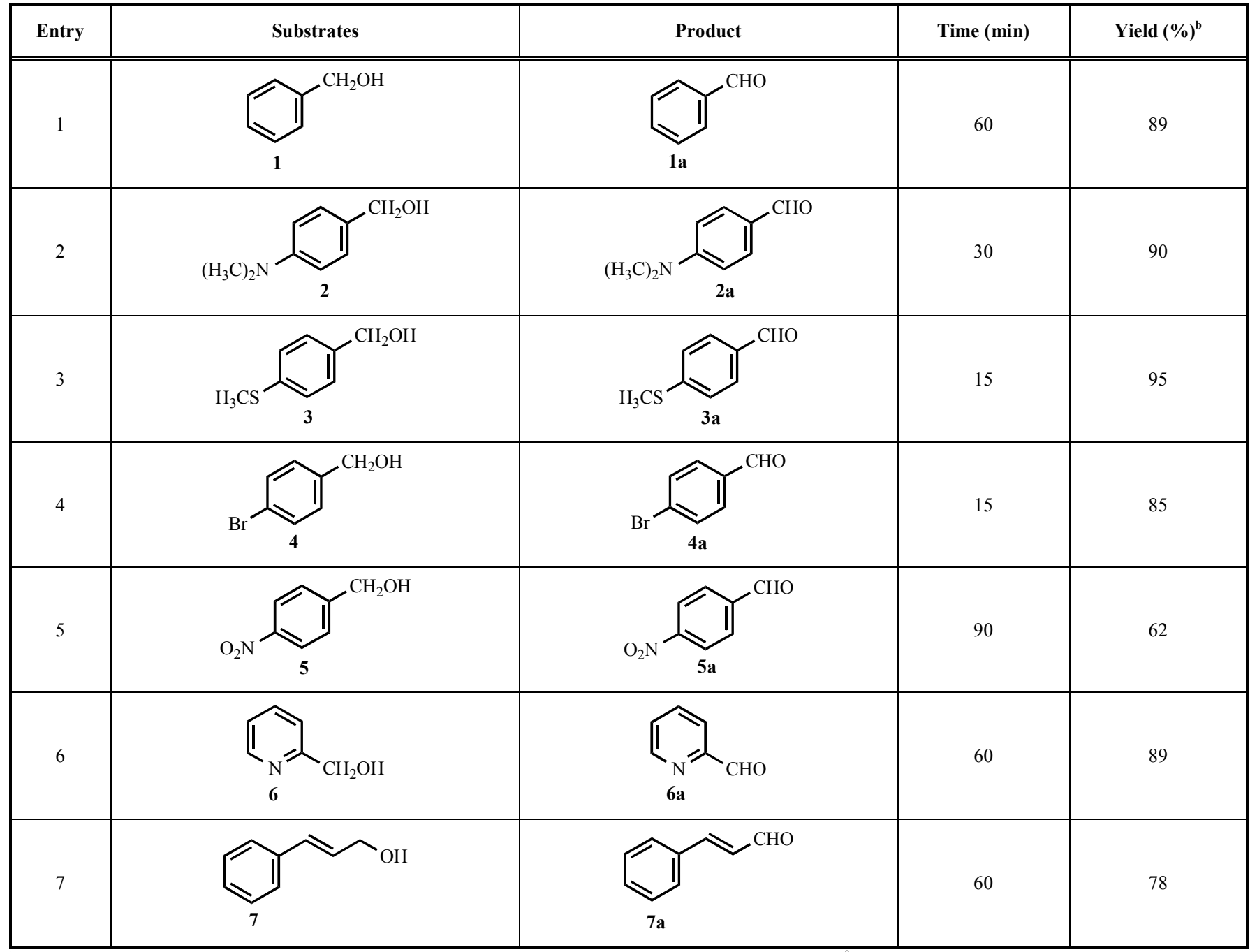

${ }^{\mathrm{a}}$ Reaction conditions: A mixture of $1 \mathrm{mmol}$ of alcohol, $5 \mathrm{~mol} \%$ of $\mathrm{MoO}_{2} \mathrm{Cl}_{2}, 5 \mathrm{~mol} \%$ of $\mathrm{Cu}\left(\mathrm{ClO}_{4}\right)_{2} \cdot 6 \mathrm{H}_{2} \mathrm{O}$ and $50 \mathrm{mg}$ of $4 \AA$ moleculer sieve was stirred under reflux condition while bubbling oxygen. Isolated yield. 


\subsection{Oxidation of Alcohols to Ketones}

The summarized results for the oxidation of secondary alcohols were provided in Table $\mathbf{3}$. Unactivated, activated and deactivated benzyl alcohols, 8-11 (Table 3, entries 8-11) were oxidized to corresponding ketones 8a-11a in above $80 \%$ of yields. Further efficiency of the $\mathrm{MoO}_{2} \mathrm{Cl}_{2} / \mathrm{Cu}\left(\mathrm{ClO}_{4}\right)_{2}$. $6 \mathrm{H}_{2} \mathrm{O}$ system was studied on oxidation of aliphatic secondary alcohols; cyclic and acylic secondary alcohols 12-14
(Table 3, entries 12-14) were oxidized to corresponding ketones 12a-14a in 52-60\% of yields. Thus aliphatic alcohols are found to be less reactive.

\subsection{Oxidation of Esters to Keto Esters}

The summarized results for the oxidation of $\alpha$ - and $\beta$ hydroxy esters are provided in Table 4. Aryl substituted $\alpha$ and $\beta$-hydroxy esters, 15- 20 (Table 4, entries 15-20) were

Table 3. Oxidation of Secondary Alcohols Using $\mathrm{MoO}_{2} \mathrm{Cl}_{2} / \mathrm{Cu}\left(\mathrm{ClO}_{4}\right)_{2} \cdot 6 \mathrm{H}_{2} \mathrm{O}$ as the Bimetallic System ${ }^{\mathrm{a}}$

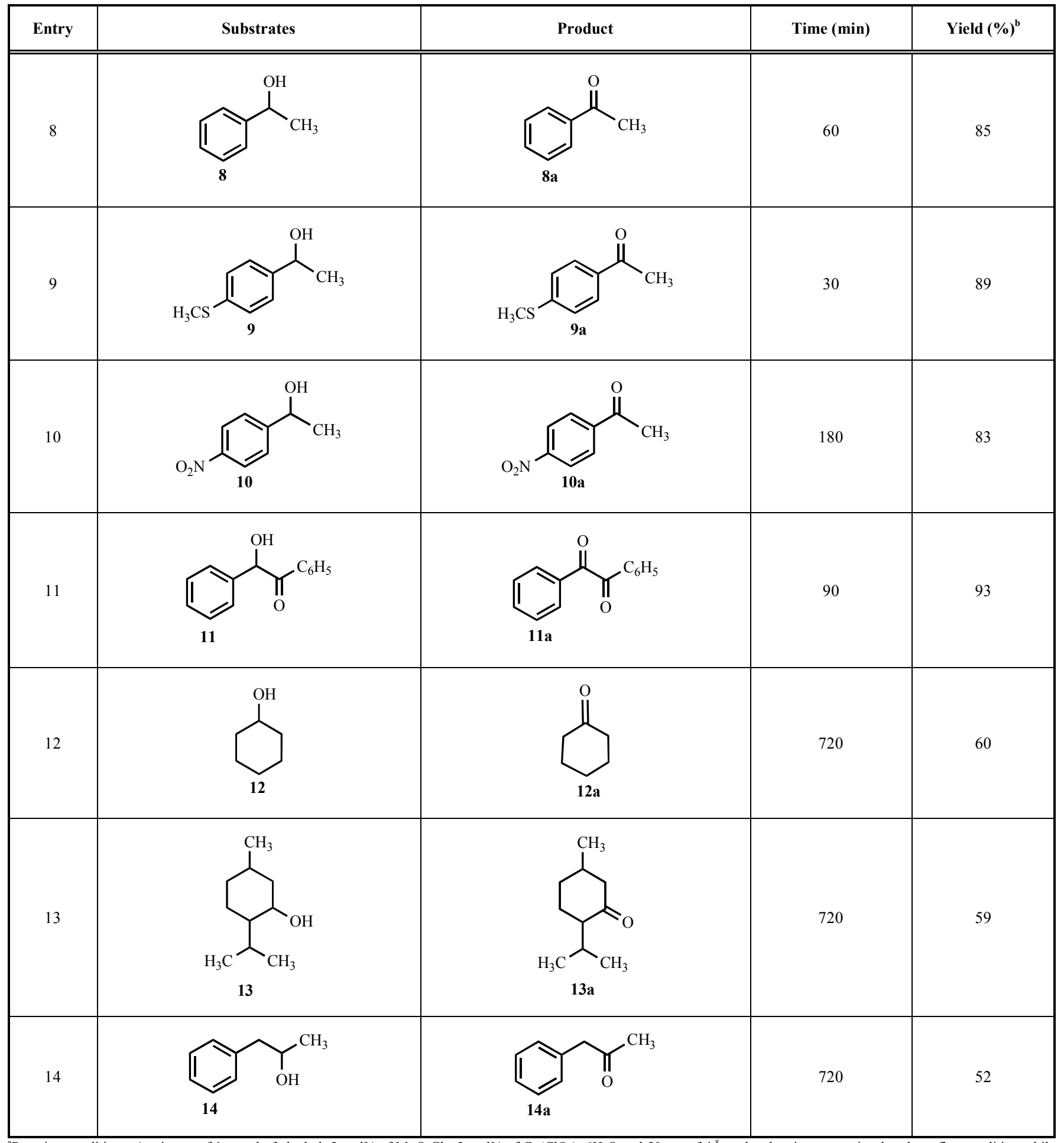


Table 4. Oxidation of $\alpha$-and $\beta$-Hydroxy Ester Using $\mathrm{MoO}_{2} \mathrm{Cl}_{2} / \mathrm{Cu}\left(\mathrm{ClO}_{4}\right)_{2} \cdot 6 \mathrm{H}_{2} \mathrm{O}$ as the Bimetallic System ${ }^{\mathrm{a}}$

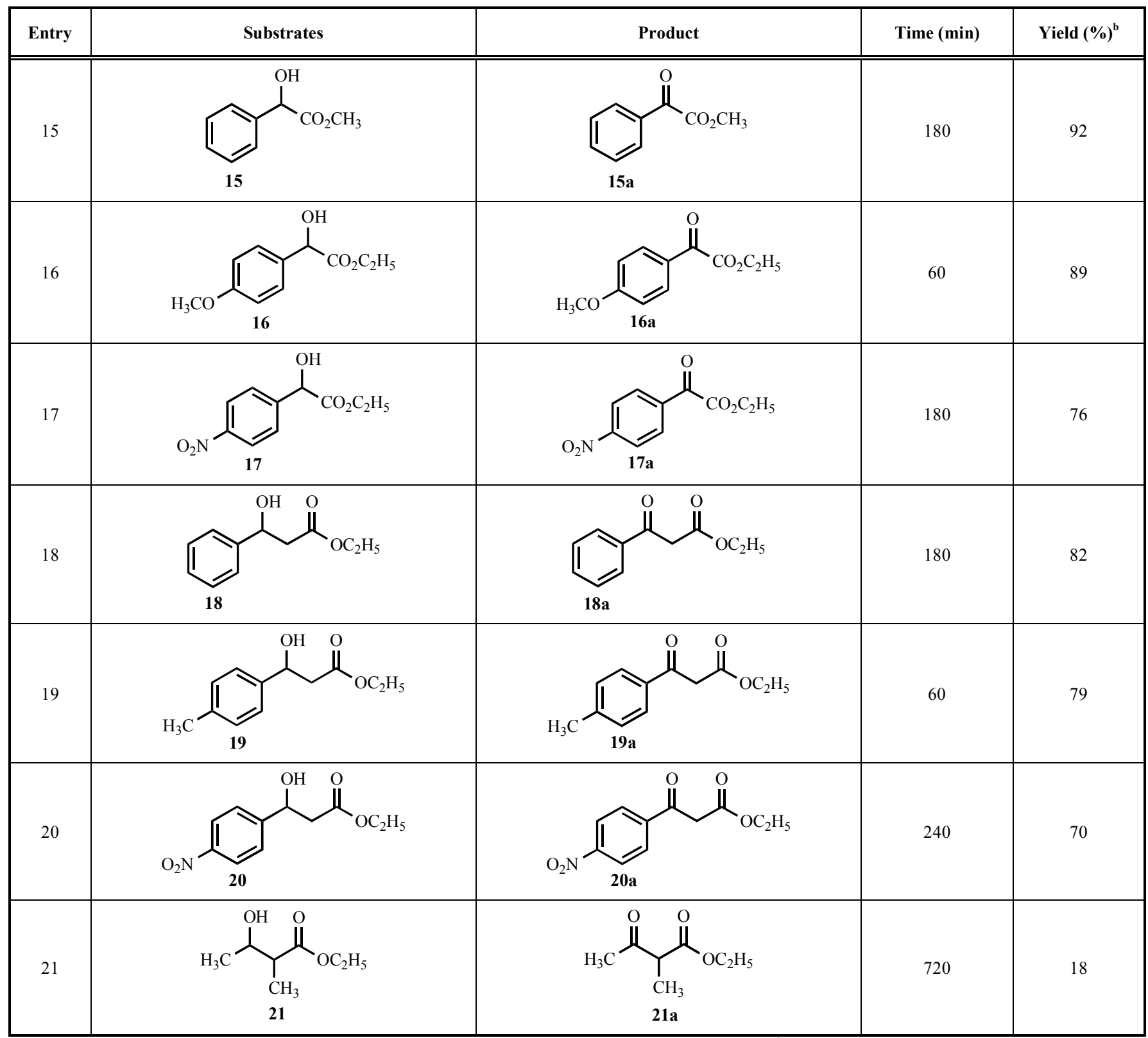

${ }^{\mathrm{a}}$ Reaction conditions: A mixture of $1 \mathrm{mmol}$ of alcohol, $5 \mathrm{~mol} \%$ of $\mathrm{MoO}_{2} \mathrm{Cl}_{2}, 5 \mathrm{~mol} \%$ of $\mathrm{Cu}\left(\mathrm{ClO}_{4}\right)_{2} \cdot 6 \mathrm{H}_{2} \mathrm{O}$ and $50 \mathrm{mg}$ of $4 \AA$ moleculer sieve was stirred under reflux condition while bubbling oxygen. ${ }^{\mathrm{b}}$ Isolated yield.

oxidized to corresponding keto esters 15a-20a in 70-92\% of yields. Alkyl substituted $\beta$-hydroxy ester 21 was oxidized to corresponding $\beta$-keto ester $\mathbf{2 1 a}$ in $18 \%$ of yield. In this class of compounds the aliphatic compounds are found to be less reactive as observed from the lower yield of the desired product.

\subsection{Mechanism of Alcohol Oxidation in the Bimetallic System}

We have studied the role of oxygen in this reaction, by oxidizing benzyl alcohol (1) under various conditions (Table 5) by controlling the atmosphere of the reaction. The reaction provides $71 \%$ benzaldehyde when exposed to air where as under bubbling oxygen $89 \%$ of benzaldehyde was obtained. Under $\mathrm{N}_{2}$ atmosphere the reaction does not proceed, which shows the participation of aerobic oxygen in the oxidation process.
During the oxidation of alcohols using the bimetallic catalyst, it is proposed that, Mo(VI) species undergoes reduction to Mo(IV) which could be re-oxidized to Mo(VI) by $\mathrm{Cu}$ (II) (Scheme 1). The $\mathrm{Cu}(\mathrm{I})$ so formed could be re-oxidized to $\mathrm{Cu}(\mathrm{II})$ by molecular oxygen [5]. These molybdenum species present in the catalytic cycle are expected to bind alcohol/alkoxide to initiate and sustain the oxidation reaction. When the Mo(IV) species is bound to alcohol/alkoxide having electron withdrawing group then the Mo(IV) center will experience decrease of electron density around it and hence oxidation to generate Mo(VI) by oxygen should be hampered. In the same line presence of electron releasing group should favor the oxidation of $\mathrm{Mo}(\mathrm{IV})$ to $\mathrm{Mo}(\mathrm{VI})$. The reactivity patterns of the alcohols to provide aldehydes support this argument. Addition of the $\mathrm{Cu}$ (II) as a cocatalyst some what circumvent this problem by activating molecular oxy- 
gen and facilitating oxidation of $\mathrm{Mo}(\mathrm{IV})$ to $\mathrm{Mo}(\mathrm{VI})$ and hence before the catalyst is deactivated oxidation of less reactive alcohols is also realised.

Table 5. Oxidtion of Benzyl Alcohol Under Various
Atmospheres

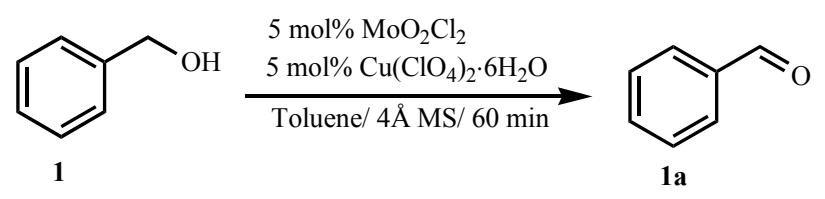

\begin{tabular}{|c|c|}
\hline Reaction Condition & Yield (\%) $^{\mathbf{b}}$ \\
\hline \hline Open air & 71 \\
\hline Under $\mathrm{O}_{2}$ & 89 \\
\hline Under $\mathrm{N}_{2}$ & $--^{\mathrm{c}}$ \\
\hline
\end{tabular}

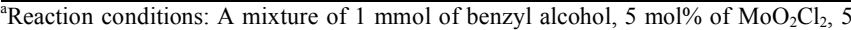
$\mathrm{mol} \%$ of $\mathrm{Cu}\left(\mathrm{ClO}_{4}\right)_{2} \cdot 6 \mathrm{H}_{2} \mathrm{O}$ and $50 \mathrm{mg}$ of $4 \AA$ moleculer sieve was stirred under reflux condition. ${ }^{b}$ Isolated yield. ${ }^{c}$ No product was detected in thin layer chromatography (TLC).

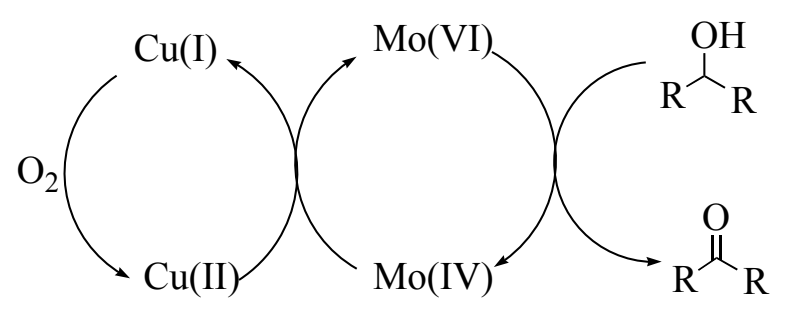

Scheme 1. Proposed mechanism for redox reactions in the bimetallic system during alcohol oxidation.

\section{CONCLUSIONS}

In conclusion, we have demonstrated the use of $\mathrm{MoO}_{2} \mathrm{Cl}_{2} / \mathrm{Cu}\left(\mathrm{ClO}_{4}\right)_{2} \cdot 6 \mathrm{H}_{2} \mathrm{O}$ as a bimetallic catalyst for alcohol oxidation. Various alcohols were oxidized to corresponding carbonyl compounds in good yields. The individual metal catalysts are found to be less efficient for alcohol oxidation. More importantly, benzyl alcohols having no ring substituent or electron withdrawing substituent could be oxidized by the bimetallic catalyst which is not possible with $\mathrm{MoO}_{2} \mathrm{Cl}_{2}$. Some oxidisable functional groups like amine, pyridine, sulfide and olefin groups are tolerated during the conversion. Synthesis of dicarbonyls is also achieved using this method.

\section{ACKNOWLEDGEMENTS}

This study was supported by a grant in aid for scientific research from the CSIR, (No. 01(2108)/07/EMR-II New Delhi, India). K. J. thanks CSIR, New Delhi for a Senior Research Fellowship.

\section{REFERENCES}

[1] Hudlicky, M. Oxidations in Organic Chemistry; ACS: Washington, DC, 1990.
[2] (a) Sheldon, R.A.; Kochi, J.K. Metal-Catalyzed Oxidations of Organic Compounds; Academic Press: New York, 1981; (b) Ley, S.V.; Norman, J.; Griffith, W.P.; Marsden, P. Synthesis, 1994, 639; (c) Cainelli, G.; Cardillo, G. Chromium Oxidations in Organic Chemistry; Springer: Berlin, 1984.

[3] (a) Arends, I. W. C. E.; Sheldon, R. A. In Modern Oxidation Methods; J.E. Bäckvall, Ed.; Wiley-VCH: Weinheim, Germany, 2004; pp. 83-118; (b) Schultz, M. J.; Sigman, M. S. Tetrahedron, 2006, 62,8227 .

[4] (a) Maignien, S.; Mohand, S.A.; Muzart, J. Synlett, 1996, 439; (b) Maiti, S. K.; Malik, K.M.A.; Bhattacharyya, R. Inorg. Chem. Commun., 2004, 7, 823.

[5] Shibasaki, M.; Yamamoto, Y. Multimetallic Catalysts in Organic Synthesis; Wiley: Weinheim, 2004.

[6] (a) Muldoon, J.; Brown, S. N. Org. Lett., 2002, 4, 1043; (b) Shapley, P. A.; Zhang, N.; Allen, J. L.; Pool, D. H.; Liang, H. C. J. Am. Chem. Soc., 2000, 122, 1079; (c) Lorber, C. Y.; Smidt, S. P.; Osborn, J. A. Eur. J. Inorg. Chem., 2000, 655.

[7] (a) Sanz, R.; Aguado, R.; Pedrosa, M. R.; Arnaiz, F. J. Synthesis, 2002, 856; (b) Sanz, R.; Escribano, J.; Aguado, R.; Pedrosa, M. R.; Arnaiz, F. J. Synthesis, 2004, 1629; (c) Sanz, R.; Escribano, J.; Fernandez, Y.; Aguado, R.; Pedrosa, M. R.; Arnaiz, F. J. Synlett, 2005, 1389; (d) Chen, C. T.; Kuo, J. H.; Pawar, V. D.; Munot, Y. S.; Weng, S. S.; Ku, C. H.; Liu, C. Y. J. Org. Chem., 2005, 70, 1188 ; (e) Fernandes, A. C.; Fernandes, R.; Romao, C. C.; Royo, B. Chem. Commun., 2005, 213; (f) Weng, S. S.; Lin, Y. D.; Chen, C.-T. Org. Lett., 2006, 8, 5633; (g) Sanz, R.; Escribano, J.; Pedrosa, M. R.; Aguado, R.; Arnaiz, F. J. Adv. Synth. Catal., 2007, 349, 713; (h) Fernandes, A. C.; Romao, C. C. Tetrahedron Lett., 2007, 48, 9176; (i) Fernandes, A. C.; Romao, C. C. J. Mol. Catal. A: Chem., 2006, 253, 96; (j) Fernandes, A. C.; Romao, C. C. J. Mol. Catal. A: Chem., 2007, 72, 60; (k) Goswami, S.; Maity, A.C.; Tetrahedron Lett., 2008, 49, 3092.

[8] (a) Jeyakumar, K.; Chand, D. K. Tetrahedron Lett., 2006, 47, 4573; (b) Jeyakumar, K.; Chand, D. K. Appl. Organomet. Chem., 2006, 20, 840; (c) Jeyakumar, K.; Chand, D. K. Synthesis, 2008, 807; (d) Jeyakumar, K.; Chand, D. K. Synthesis, 2008, 1685; (e) Jeyakumar, K.; Chand, D. K. Synthesis, 2008, (in press); (f) Jeyakumar, K.; Chand, D. K. J. Mol. Cata. A: Chem., 2006, 255, 275.

[9] (a) Mohanazadeh, F.; Hosini, M.; Tajbakhsh, M. Monatsh. Chem., 2005, 13, 2041-2043; (b) Ianni, A.; Waldvogel, S. R. Synthesis, 2006, 2103; (c) Fosdick, L. S.; Wessinger, G. D. J. Am. Chem. Soc., 1938, 60, 1465; (d) Beignet, J.; Cox, L. R. Org. Lett., 2003, 5, 4231; (e) Bang, K.; Lee, K.; Park, Y. K.; Lee, P. H. Bull. Korean Chem. Soc., 2002, 23, 1272; (f) Xu, L.; Cheng, J.; Trudell, M.L. J. Org. Chem., 2003, 68, 5388; (g) Nakamura, K.; Miyai, T.; Nozaki, K.; Ushio, K.; Oka, S.; Onho, A. Tetrahedron Lett., 1986, 27, 3155. [10] Armarego, W. L. F.; Perrin, D. Purification of Laboratory Chemicals, 4th ed.; Butterworth-Heinemann: Oxford, 2002.

[11] Analytical data for the products: (a) Gogoi, P.; Hazarika, P.; Konwar, D. J. Org. Chem., 2005, 70, 1934; (b) Schultz, M. J.; Hamilton, S.S.; Jensen, D. R.; Sigman, M. S. J. Org. Chem., 2005, 70, 3343; (c) Ali, M. H.; Stricklin, S. Synth. Commun., 2006, 36, 1779; (d) Baciocchi, E.; Gerini, M.F.; Lapi, A. J. Org. Chem., 2004, 69, 3586; (e) Jiang, N.; Ragauskas, A. J. Org. Lett., 2005, 7, 3689; (f) Singh, R. P.; Kamble, R. M.; Chandra, K. L.; Saravanan, P.; Singh, V. K. Tetrahedron 2001, 57, 241; (g) Zheng, Z. H.; Tang, Y. J. Org. Chem., 2002, 67, 5320; (h) Velusamy, S.; Punniyamurthy, T. Org. Lett., 2004, 6, 217; (i) Tran, K. V.; Bickar, D. J. Org. Chem., 2006, 71, 6640; (j) Jain, S. L.; Sharma, V. B.; Sain, B. Tetrahedron, 2006, 62, 6841; (k) Shimizu, H.; Murakami, M. Chem. Commun., 2007, 2855; (l) Makosza, M.; Sienkiewicz, K.; Wojciechowski, K. Synthesis, 1990, 850; (m) Balaji, B. S.; Chanda, B. M. Tetrahedron, 1998, 54, 13237; (n) Elaridi, J.; Thaqi, A.; Prosser, A.; Jackson, W. R.; Robinson, A. J. Tetrahedron: Asymmetry, 2005, 16, 1309. 